\title{
OPTIMALISASI APLIKASI E-COMMERCE UNTUK PENJUALAN PADA TOKO DESFA BOGOR
}

\author{
Nur Azizah ${ }^{1}$ \\ Erna Astriyani ${ }^{2}$ \\ Listina Nadhia $\mathrm{N}^{3}$
}

nur.azizah@raharja.info, erna.astriyani@ raharja.info, listina.nadhia@ raharja.info

\begin{abstract}
ABSTRAK
Dalam era globalisasi sekarang ini, teknologi informasi melaju dengan cepatnya. Adapun komputer yang merupakan peralatan yang diciptakan untuk mempermudah pekerjaan manusia, saat ini mencapai kemajuan baik di dalam pembuatan hardware maupun software. Toko Desfa sangat membutuhkan sekali adanya suatu sistem informasi yang menunjang dan memberikan pelayanan yang memuaskan bagi para konsumen. Untuk itulah penulis mencoba membuat Tugas Akhir mengenai aplikasi e-commerce penjualan busana muslim pada Toko Desfa yang sampai saat ini masih menggunakan cara konvensional. Pada saat ini Toko Desfa berupa toko yang menjual busana muslimah saja. Mekanisme penjualan yang ada pada Toko Desfa yaitu konsumen dapat datang langsung dan memilih busana yang akan dibelinya. Aplikasi e-commerce merupakan solusi yang terbaik untuk menciptakan ruang lingkup penjualan yang lebih luas lagi dan juga untuk mengembangkan bisnis penjualannya. E-commerce merupakan salah satu sarana yang tepat untuk mempromosikan produk yang ada pada Toko Desfa, dengan memanfaatkan Sistem Informsi dan juga internet dapat tercapai suatu sistem yang sangat efektif dan efisien dalam menunjang kegiatan pada toko ini.
\end{abstract}

Kata Kunci: Aplikasi E-commerce, Sistem Informasi Penjualan

\begin{abstract}
In the current era of globalization, information technology drove rapidly. The computers are tools created to facilitate human work, currently in progress both in the manufacture of hardware and software. Shop Desfa desperately need once the existence of an information system to support and provide satisfactory service for consumers. To which the author tries to make the final application of e-commrece sales in the muslim fashion store Desfa that is still using conventional means. At this time in the from Desfa shop selling Muslim clothing store alone. Sales of existing mechanisms to store Desfa that consumers can come directly and choose the clotes that will be bought. Aplication of e-commerce is the best solution for creating a scope broader sales and also to develop bussines sales. E-commerce is one of the appropriate means to promote existing products on store Desfa, by utilizing information System and the internet also can achieve a system that is higly effective and efficient in supporting the activities at this store.
\end{abstract}

Keyword: Applications E-commerce, Sales Information System

\section{PENDAHULUAN}

\section{Latar Belakang \\ Kehadiran memberikan internet telah pentingnya teknologi didalam pencapaian tujuan finansial suatu}

perusahaan melalui modifikasi dan efisiensi proses bisnis yaitu dengan memungkinkan terjadinya kegiatan perdagangan menggunakan media elektronik yang biasa disebut dengan electronic commerce atau biasa dikenal dengan sebutan E-commerce. Seiring berkembangnya dunia 
teknologi, semakin banyak pula kalangan yang mengakses internet dalam kehidupan sehari-harinya, sehingga banyak perusahaan atau organisasi yang menggunakan website sebagai sarana promosi berbisnis. Belakangan ini dunia mode busana muslim semakin berkembang dengan maraknya komunitas pemakai hijab, khususnya kelompok remaja dalam mengenakan busana muslim semakin meningkat. Tanpa meninggalkan kesan tidak ketinggalan jaman membuat produk busana muslim laris diburu konsumen. Kondisi tersebut berdampak pada meningkatnya kebutuhan busana muslim dipasaran. Menurut Rizagana dan Farid Firdaus dalam investor.co.id (2013) menyimpulkan bahwa "bisnis $e$ commerce akan melesat, baik dari segi nilai maupun jumlah transaksi. Riset Ideasource memperkirakan, nilai transaksi bisnis e-commerce di Indonesia pada akhir tahun 2014 akan mencapai US\$ 776 juta atau sekitar Rp 9 triliun".

Oleh sebab itu penulis mencoba membantu Toko Desfa yang sampai saat ini masih menggunakan cara konvensional dalam penjualan. Toko Desfa adalah toko yang bergerak dalam bidang penjualan busana muslim. Mekanisme penjualan yang ada di Toko Desfa yaitu konsumen dapat datang langsung dan memilih busana yang akan dibelinya. Untuk menciptakan ruang lingkup penjualan dan promosi yang lebih luas dan juga mengembangkan bisnis usaha penjualannya, maka Toko Desfa perlu menerapkan suatu sistem penjualan secara online.

Atas dasar identifikasi masalah yang telah dipaparkan diatas, maka rumusan masalah adalah bagaimana membangun aplikasi e-commerce pada Toko Desfa untuk mengembangkan bisnis usaha penjualan, menciptakan ruang lingkup yang lebih luas dan juga mempermudah konsumen untuk mendapatkan informasi terbaru dan melakukan transaksi tanpa harus mengunjungi toko.

\section{Definisi Sistem}

Menurut Sutarman (2014:13), 'Sistem adalah kumpulan elemen yang saling berhubungan dan berinteraksi dalam satu kesatuan untuk menjalankan suatu proses pencapaiansuatu tujuan utama".

Dari pendapat yang dikemukakan diatas dapat disimpulakn bahwa sistem adalah suatu kumpulan atau kelompok dari elemen atau komponen yang saling berhubungan atau saling berinteraki dan saling bergantung satu sama lain untuk mencapai tujuan tertentu.

Menurut Jogiyanto dalam Jurnal CCIT Vol 7 No 1 (September 2013:116), Pengertian sistem dapat didefinisikan dengan pendekatan prosedur yaitu kumpulan dari prosedur-prosedur yang mempuyai tujuan tertentu.Sistem juga dapat didefinisikan dengan pendekatan komponen yaitu kumpulan dari komponen yang saling berhubungan satu dengan yang lainnya membentuk satu kesatuan untuk mencapai tujuan tertentu.

\section{Pengertian Informasi}

Menurut Sutarman (2014:14), "Informasi adalah sekumpulan fakta (data) yang diorganisasikan dengan cara tertentu sehingga mereka mempunyai arti bagi si penerima".

Menurut McLeod yang dikutip dari Yakup (2012:8), "Informasi adalah data yang diolah menjadi bentuk yang lebih berguna bagi penerimanya".

Berdasarkan pendapat para ahli yang dikemukakan diatas dapat ditarik kesimpulan bahwa informasi adalah 
data yang sudah diolah menjadi sebuah bentuk yang berarti bagi penggunanya, yang bermanfaat dalam pengambilan keputusan saat ini atau mendukung sumber infomasi.

\section{Definisi Sistem Informasi}

$\begin{array}{lr}\text { Menurut } & \begin{array}{c}\text { Sutarman } \\ \text { informasi }\end{array} \\ \text { "Sistem } & \text { dapat } \\ \text { didefinisikan } & \text { dengan } \\ \text { mengumpulkan, } & \text { memproses, } \\ \text { menyimpan, } & \text { menganalisis, }\end{array}$
menyebarkan informasi untuk tujuan tertentu".Seperti sistem lainnya, sebuah sistem informasi terdiri atas input (data, instruksi) dan output (laporan, kalkulasi). Dari pendapat yang dikemukakan diatas dapat disimpulkan bahwa informasi adalah gabungan dari orang, hardware, software, jaringan komunikasi, sumber daya data, dan kebijakan dan prosedur yang menyimpan, mengumpulkan (mendapatkan kembali), memproses dan mendistribusikan informasi untuk mendukung pengambilan dan pengontrolan keputusan dalam suatu organisasi.

a. Pengertian Sistem Informasi Berbasis Komputer

Menurut Yustianti (2012:14), "Teknologi Informasi adalah komponen tertentu pada sebuah sistem. Namun, hanya sedikit teknologi informasi yang digunakan secara terpisah".

Menurut Sutarman (2012:14), "Sistem informasi berbasis komputer adalah sebuah sistem inforamasi yang menggunakan komputer dan teknologi telekomunikasi untuk melakukan tugas-tugas yang diinginkan".Dari pendapat yang dikemukakan di atas dapat disimpulkan bahwa Teknologi Informasi dan Sistem Informasi Berbasis Komputer adalah komponen tertentu pada sebuah sistem secara yang menggunakan komputer dan teknologi telekomunikasi untuk melakukan tugas-tugas yang diinginkan.

b. Komponen Sistem Informasi

Menurut Sutabri (2012:39), Sistem informasi mempunyai enam buah komponen, yaitu komponen masukan (input), komponen model, komponen keluaran (output), komponen teknologi, komponen basis data dan komponen kontrol atau pengendalian.

1. Komponen Masukan (input) Input merupakan data yang masuk kedalam sistem informasi. Komponen ini perlu ada karena merupakan bahan dasar dalam pengolahan informasi.

2. Komponen Model Informasi yang dihasilkan oleh sistem informasi berasal dari data yang diambil dari basis data yang diolah lewat suatu model- model tertentu.

3. Komponen Keluaran (output)

Produk dari sistem informasi adalah Output berupa informasi yang berguna bagi para pemakainya. Output merupakan komponen yang harus ada di sistem informasi.

4. Komponen Teknologi

Teknologi merupakan komponen sistem yang penting pada sistem informasi. Tanpa adanya teknologi yang mendukung, maka sistem informasi tidak akan dapat menghasilkan informasi tepat pada waktunya.

5. Komponen Basis Data

Basis data (database) merupakan kumpulan dari data yang saling berhubungan satu dengan yang lainnya, tersimpan diperangkat keras komputer, dan digunakan 
perangkat lunak untuk memanipulasinya. Data perlu disimpan didalam basis data untuk keperluan penyediaan informasi.

6. Komponen Kontrol atau Pengendalian

Komponen kontrol merupakan komponen yang penting dan harus ada dalam sistem informasi.Komponen kontrol ini digunakan untuk menjamin bahwa informasi yang dihasilkan oleh sistem informasi merupakan informasi yang kuat.

\section{Pengertian Internet}

Dalam perkembangan teknologi di zaman globalisasi ini pasti sudah banyak yang mengenal kata internet. Adapun kata internet sering didengar baik melalui media televisi maupun media informasi lainnya, yang dapat membantu seseorang dalam menyebarluaskan informasi kepada orang lain, sebagai contohnya dalam perusahaan dalam memasarkan produknya dapat mempergunakan media ini.

Internet berasal dari bahasa latin "inter" yang berarti "antara", secara kata per kata Internet berarti jaringan antara atau penghubung. Menurut Sunarto (2009:40) mengemukakan bahwa "Internet adalah jaringan komputer yang saling terhubung ke seluruh dunia tanpa mengenal batas teritorial, hukum dan budaya". Secara fisik dianalogikan sebagai jaringan laba-laba (The Web) yang menyelimuti bola dunia dan terdiri dari titik-titik (node) yang saling berhubungan.

Node bisa berupa komputer, jaringan lokal atau peralatan komunikasi, sedangkan garis penghubung antara simpul disebut tulang punggung (back bone) yaitu media komunikasi terestrial (kabel, serat optik, microwave, radio link) maupun satelit. World Wide Web (W3) atau yang dikenal juga dengan istilah web adalah suatu sistem yang berkaitan dengan dokumen digunakan sebagai media untuk menampilkan teks, gambar, multimedia dan lainnya pada jaringan internet. Selain W3 ada juga Web Server.

\section{Dreamweaver CS4}

Adobe Dreamweaver yang dulunya adalah pengembangan aplikasi web milik awalnya diciptakan oleh Macromedia, dan sekarang dikembangkan oleh Adobe Systems, yang mengakuisisi Macromedia pada tahun 2005.

Menurut Hadi (2009:2) mengemukakan seorang desainer web profesional ingin membuat sebuah website, mereka akan memilih dreamwever sebagai editornya. Survey membuktikan $80 \%$ desainer web menggunakan program ini, hal ini tak luput karena dreamwever dapat dijalankan pada dua platform Windows dan Mac. Penyempurnaan dan peningkatan fitur pun terus dilakukan dari waktu ke waktu untuk memenuhi kebutuhan akan pengguna $\mathrm{Web}$.

Kini perusahaan adobe kembali hadir dan menawarkan Dreamwever CS4 lebih menjadi kreatif dalam membuat Website. Dreamwever menjadi lebih sempurna karena memiliki sifat What You See Is What You Get, dengan arti kode yang dibuat untuk membangun website berbentuk HTML, cukup dengan memasukan file text, graphics dan media lainnya karena dreamwever menyediakan jendela preview Code dan Desaign.

\section{Personal Home Page (PHP)}

Menurut Raharjo dkk (2010:41) mengemukakan bahwa "PHP (Personal Hypertext Preprocessor) adalah bahasa pemrograman skrip yang dirancang untuk membangun aplikasi web". Ketika dipanggil dari 
web browser, program yang ditulis dengan PHP akan di parsing dalam web server oleh interpreter. PHP akan diterjemahkan ke dalam dokumen HTML yang selanjutnya akan ditampilkan kembali ke web browser, karena pemrosesan program PHP dilakukan dilingkungan web server.

PHP dikatakan sebagai bahasa sisi server (server-side), karena kode PHP tidak akan terlihat pada saat user memilih perintah "View Source" pada web browser. Selain menggunakan PHP, aplikasi web juga dapat dibangun dengan Java (JSP - JavaServer. Pages dan Servlet), Perl, maupun ASP (Active Server Pages).

\section{HyperText Markup Language (HTML)}

Menurut Larry (2012:3) mengemukakan bahwa "HTML adalah suatu metode untuk mengimplementasikan konsep hypertext dalam suatu naskah atau document". HTML sendiri bukan tergolong pada suatu bahasa pemrograman karena sifatnya hanya memberikan tanda (Marking up) pada suatu naskah text bukan sebagai program. Pengertian HTML bila dijabarkan berdasarkan kata-kata penyusunan HTML dapat diartikan lebih dalam lagi menjadi:

a. HyperText adalah kata atau frase yang dapat menunjukan hubungan satu naskah dokumen dengan naskah-naskah lainnya.

b. MarkUp adalah file HTML yang berisi suatu intruksi tertentu yang dapat memberikan suatu format pada dokumen yang akan ditampilkan pada World Wide Web.

c. Language adalah bahasa pemrograman HTML merupakan kumpulan dari beberapa instruksi yang dapat digunakan untuk mengubah format suatu naskah atau dokumen.

Pada awalnya HTML dikembangkan sebagai SubSet SGML (Standard Generalized MarkUp Languange) karena HTML didedikasikan untuk ditransmisikan melalui media internet, maka HTML relatif lebih sederhana daripada SGML yang lebih ditekankan pada format dokumen yang berorientasi pada aplikasi.

\section{9. $M y S Q L$}

Menurut Arief (2005:151) mengemukakan bahwa "MySQL adalah salah satu jenis database serve yang sangat terkenal dan banyak digunakan untuk membangun aplikasi web yang menggunakan database sebagai sumber dan pengelolaan datanya". Kepopuleran $M y S Q L$ antara lain karena $M y S Q L$ menggunakan $S Q L$ sebagai bahasa dasar untuk mengakses database-nya sehingga mudah untuk digunakan, kinerja query cepat, dan mencukupi untuk kebutuhan database perusahaan-perusahaan skala menengah-kecil. MySQL juga bersifat open source dan free (Anda tidak perlu membayar untuk menggunakannya) pada berbagai platform (kecuali pada Windows yang bersifat shareware). MySQL didistribusikan dengan lisensi open source GPL (General Public License) mulai versi 3.32, pada bulan Juni 2000. Software MySQL bisa diunduh di http://www.mysql.org atau http://www.mysql.com.

Menurut Arief (2005:151) mengemukakan bahwa " $M y S Q L$ merupakan database yang pertama kali didukung oleh bahasa pemrograman script untuk internet (PHP dan Perl)". MySQL dan PHP dianggap sebagai pasangan software 
pengembangan aplikasi web yang ideal. $M y S Q L$ lebih sering digunakan untuk membangun aplikasi berbasis web, umumnya pengembangan aplikasinya menggunakan bahasa pemrograman script PHP.

\section{PERMASALAHAN}

a. Konsumen masih harus datang mengunjungi toko untuk membeli, hal ini menyebabkan berkurangnya minat pembeli.

b. Jangkauan promosi yang lingkupnya sangat kecil, tidak bisa diketahui banyak konsumen sehingga usaha menjadi sulit berkembang.

c. Belum ada system yang otomatis meng-update informasi barang penjualan dan pemasaran yang dapat di kenal oleh masyarakat luas sehingga secara otomatis dapat meningkatkan penjualan.

\section{METODE PENELITIAN}

Menurut Pressman (2010:39) waterfall adalah model klasik yang bersifat sistematis, berurutan dalam membangun software.

Fase-fase dalam model waterfall menurut referensi Pressman (2010:39):

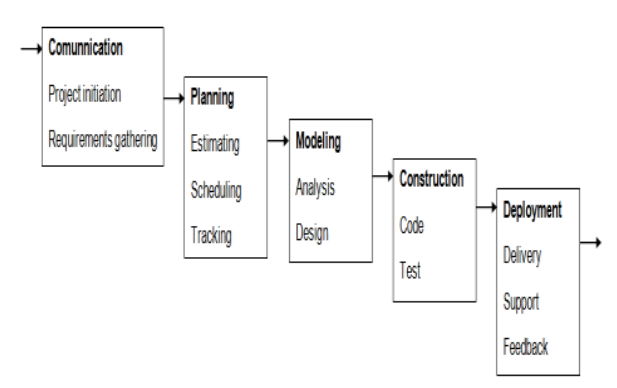

\section{Gambar 1 Sumber: Pressman (2010:39) Waterfall Model}

\section{Communication}

Langkah ini merupakan analisis terhadap kebutuhan software, dan tahap untuk mengadakan pengumpulan data dengan melakukan pertemuan dengan customer, maupun mengumpulkan data-data tambahan baik yang ada di jurnal, artikel, maupun dari internet.

\section{Planning}

Proses planning merupakan lanjutan dari proses communication (analysis requirement). Tahapan ini akan menghasilkan dokumen user requirement atau bisa dikatakan sebagai data yang berhubungan dengan keinginan user dalam pembuatan system, termasuk rencana yang dilakukan.

\section{Modeling}

Proses modeling ini akan menerjemahkan syarat kebutuhan ke sebuah perancangan system yang dapat diperkirakan sebelum dibuat coding. Proses ini berfokus pada rancangan struktur data, arsitektur system, representasi interface, dan detail (algoritma) prosedural. Tahapan ini akan menghasilkan dokumen yang disebut system requiement.

\section{Construction}

Contruction merupakan proses membuat kode. Coding atau pengkodean merupakan penerjemah desain dalam bahasa yang bisa dikenali oleh komputer. Programmer akan menerjemahkan transaksi yang diminta oleh user. Tahapan inilah yang merupakan tahapan secara nyata dalam mengerjakan suatu system, artinya penggunaan komputer akan dimaksimalkan dalam tahapan ini. Setelah pengkodean selesai maka akan dilakukan testing terhadap sistem yang telah dibuat tadi. Tujuan testing adalah menemukan kesalahan-kesalahan terhadap sistem tersebut untuk kemudian bisa diperbaiki.

\section{Deployment}

Tahapan ini bisa dikatakan final dalam pembuatan sebuah software 
atau sistem. Setelah melakukan analisis, desain dan pengkodean maka sistem yang sudah jadi akan digunakan oleh user. Kemudian system yang telah dibuat harus dilakukan pemeliharaan secara berkala.

Nama model ini sebenarnya adalah "Linear Sequential Model". Model ini sering disebut dengan "classic life cycle" atau model waterfall. Model ini adalah model yang muncul pertama kali yaitu sekitar tahun 1970 sehingga sering dianggap kuno, tetapi merupakan model yang paling banyak dipakai didalam Software Engeneering (SE). Model ini bersifat runtun dan sistematis, sehingga fase sebelumnya harus lengkap dan selesai dahulu sebelum mengerjakan fase berikutnya.

Sesuai dengan namanya waterfall (air terjun) maka tahapan dalam model ini disusun bertingkat, setiap tahap dalam model ini dilakukan berurutan, satu sebelum yang lainnya (lihat tanda anak panah), Selain itu dari satu tahap kita dapat kembali ketahap sebelumnya. Model ini biasanya digunakan untuk membuat sebuah system dalam skala besar dan yang akan dipakai dalam waktu yang lama.

Keunggulan dari sistem ini adalah:

1. system yang dikembangkan dengan metode ini biasanya menghasilkan kualitas yang baik.

2. Dokumentasi pengembangan sistem sangat terorganisir, karena setiap fase harus terselesaikan dengan lengkap sebelum melakukan fase berikutnya.

Sedangkan Kekurangannya adalah:

1. Membutuhkan keahlian yang baik atau yang telah berpengalaman dalam mengembangkan perangkat lunak, dalam arti metode ini kurang cocok bagi pemula.

2. Diperlukan menejemen yang baik, kerana proses pengembangan tidak dapat berulang sebelum menghasilkan suatu produk, yaitu aplikasi. Jadi apabila dalam suatu proses seperti perancangan tidak selesai tepat waktu, maka akan mempengaruhi keseluruhan proses pengembangan perangkat lunak.

3. Iterasi sering terjadi menyebabkan masalah baru

4. Client kesulitan menyatakan semua keinginannya secara eksplisit diawal tahap pembangunan.

\section{PEMBAHASAN DAN \\ IMPLEMENTASI}

Berdasarkan hasil analisa yang sudah dilakukan pada sistem penjualan online yang berjalan pada salah satu komunitas produk DEFAS COLLECTION, maka sistem yang dirancang adalah dengan penambahan database untuk menunjang transaksi pembelian yang dilakukan, sehingga diharapkan system yang dirancang ini dapat meningkatkan ketelitian proses transaksi penjualan, pencarian data dengan cepat dan pembuatan laporan menjadi mudah.

\section{Rancangan Basis Data}

Sebuah website memerlukan basis data sebagai tempat untuk pengelolaandanpenyimpanan

datanya. Didalam rancangan basis data akan menghasilkan sebuah pemetaan yang ada pada basis data tersebut. Pada tahap ini penulis akan menggambarkan hasil pemetaan tabel-tabel pada website toko desfa dalam bentuk entity relationship 
diagram dan logical record structure.

\section{A. Entity Relationship Diagram} (ERD)

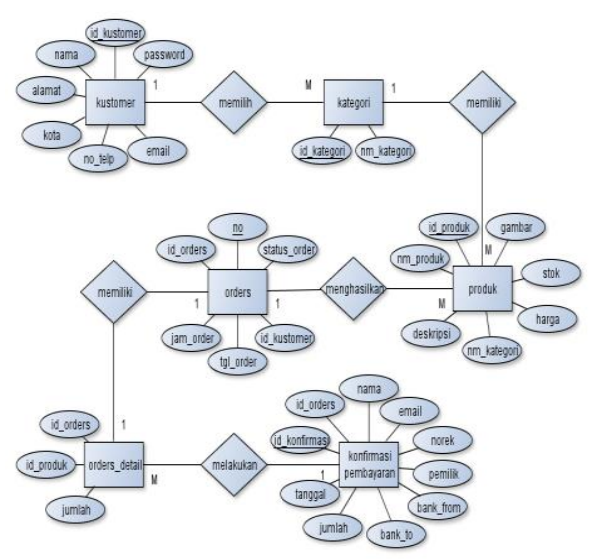

\section{Gambar 2 Entity Relationship Diagram}

Berdasarkan gambar 1 diatas pada rancangan E-R diagram dapat dideskripsikan sebagai berikut: custumer melakukan pengisian form pemesanan barang dan mengkonfirmasikan apakah barang yang dipesan tersedia, bila ada maka dilakukan transaksi pembelian sesuai dengan kesepakatan. Produk-produk yang dapat dilihat dikatalog produk sebelum dilakukan transaksi. Adapaun tampilan Logical Record Structure (LRS) yang dibentuk dengan nomor dari tiap record ilustrasinya dapat dilihat pada gambar 2 berikut:

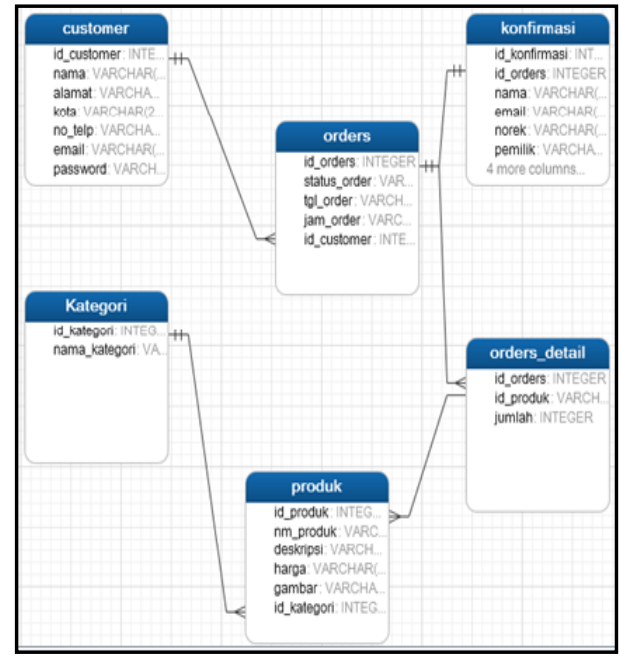

Gambar 3 Logical Record Structure

\section{Rancangan Aplikasi}

Dalam rancangan website ini, penulis akan membuat website yang akan memudahkan para pengguna untuk memperoleh informasi dalam mengakses informasi ataupun melakukan transaksi pembelian secara online. Atas dasar analisa kebutuhan yang telah dijelaskan diatas maka penulis membagi website ini menjadi 2 bagian, yaitu:

\section{Halaman Admin}

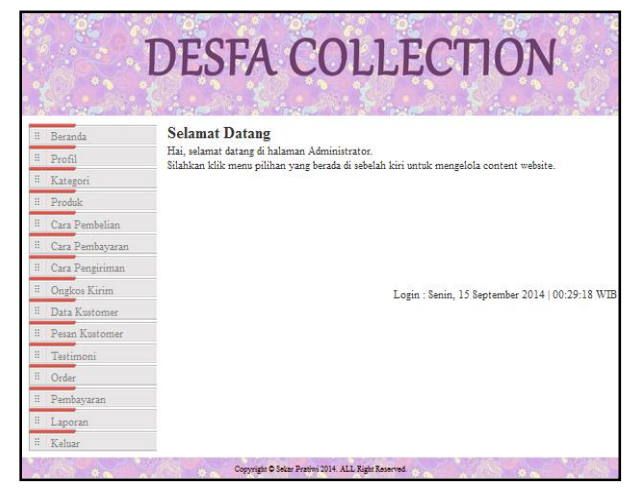

Gambar 4. Halaman Admin

Halaman admin ini adalah halaman yang hanya dikelola oleh administrator. Pada halaman admin ini penulis menyediakan penambahan stok produk, kategori, menampilkan data pelanggan, 
menampilkan pesanan yang masuk, lihat dan cetak laporan dan tentunya fasilitas pengeditan untuk memudahkan para admin dalam mengelola website ini.

\section{Halaman Pengunjung}

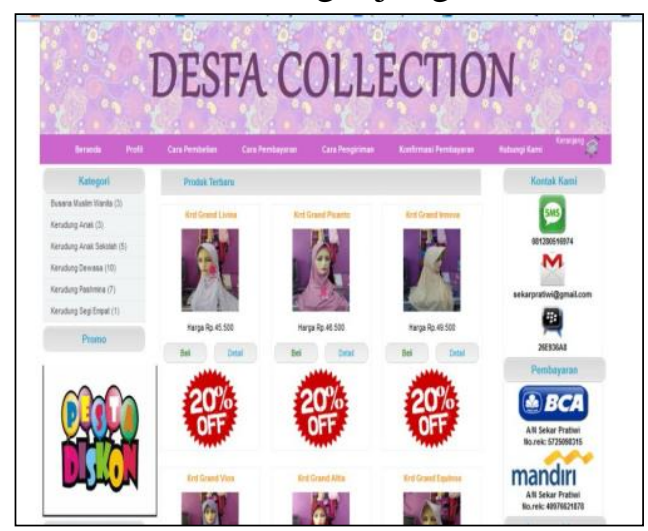

Gambar 5. Halaman Pengunjung

Di dalam halaman pengunjung ini, pengunjung dapat langsung melihat produk-produk yang sedang ada promo atau potongan harga yang dimiliki toko dan juga dapat memilih langsung produk yang akan dibeli. Selain memilih produk, pengunjung juga dapat memberikan komentar mereka tentang website ini pada halaman testimonial yang telah disediakan. Selain itu pengunjung dapat berkomunikasi langsung dengan admin yang mengontrol penjualan di website. Dan untuk melanjutkan proses transaksi pengunjung diharuskan mendaftar terlebih dahulu, yang sebelumnya sudah mendaftar pada website ini dapat langsung login pada form yang telah disediakan.
3. Halaman Laporan

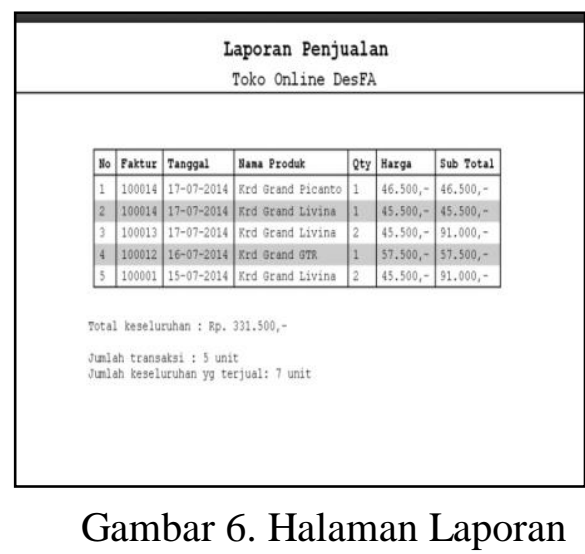

Gambar 6 merupakan contoh hasil generalisasi transaksi yaitu halaman laporan. Setiap data transaksi penjualan yang terjadi pada sistem online ini akan tersimpan dalam database yang prosesnya secara otomatis digeneralisasi ke dalam bentuk report yang digunakan setiap akhir bulan untuk diserahkan kepada pimpinan.

\section{KESIMPULAN}

a. Sistem informasi e-commerce pada Toko Desfa yang menyediakan fasilitas bagi para konsumen untuk mendapatkan informasi serta memberikan kebebasan kepada konsumen untuk melihat-lihat, memilih dan membeli produk tanpa harus mengunjungi toko.

b. Sistem informasi e-commerce membantu Toko Desfa dalam mempromosikan dan menjual produk kepada konsumen sehingga informasi makin up to date dan usahanya dapat semakin berkembang.

c. Dengan kemudahan meluasnya informasi, akan semakin banyak pula pelanggan Toko Desfa, maka secara otomatis dapat meningkatkan penjualan dan pendapatan. 


\section{DAFTAR PUSTAKA}

1. Arief, M Rudyanto. 2011. Pemrograman Web Dinamis Menggunakan PHP \& MySQL. Yogyakarta: ANDI.

2. Hadi, Mulya. 2009. 7 Jam Belajar Interaktif DREAMWEAVER CS4 untuk Orang Awam. Palembang: Maxikom.

3. MartonoAris, Padeli, Fitria Dina Murad. (2010).

"PengembanganSistem

Database Penempatan Tenaga Kerja Berbasis Web" 2(3), 307.Jurnal CCIT.Tangerang.

4. Larry, Roy. 2012. Jurus Kilat Mahir HTML \& CSS. Jakarta: Dunia komputer.

5. Pressman, RS. 2010. Software engineering : a apractitioner's approach. New York McGraw Hill.

6. Raharjo, Budi, Imam dan Enjang RK. 2010. Modul Pemrograman WEB (HTML, PHP, MYSQL). Bandung: Modula.

7. Rizagana dan Farid Firdaus. 2013. 2014, Tahun Kebangkitan ECommerce Indonesia. Diambil dari:http://www.investor.co.id/ho me/2014-tahun-kebangkitan-ecommerce-indonesia/74271. (24 Mei 2014)

8. Sunarto, Andi. 2009. Seluk Beluk E-Commerce. Yogyakarta: Garailmu.

9. Sutarman. 2012. "Buku Pengantar Teknologi Informasi”. Jakarta:BumiAksara.

10. Sutabri, Tata. 2012. "Konsep Sistem Informasi”. Yogyakarta: Andi Offset

11. Yakub. 2012. Pengantar Sistem

Informasi",Yogyakarta:GrahaIlmu

12. Yustianti.2012. "Buku Pengantar Teknologi Informasi". Jakarta:Bumi Aksara. 